https://doi.org/10.31470/2706-7904-2020-15-238-240

\title{
МОВА І МОВЛЕННЯ ЯК ЧИННИК АКУЛЬТУРАЦЇ̈ ІНОЗЕМНИХ СТУДЕНТІВ
}

\section{Language and Speech as a Factor of Acculturation of International Students}

\author{
Inna Tarasiuk \\ Ph.D. in Psychology, Associate Professor \\ Lesya Ukrainka Volyn National University (Ukraine) \\ Tarasiuk.Inna@vnu.edu.ua \\ https://orcid.org/0000-0002-6026-3545
}

\begin{abstract}
The abstract reveal the problem of acculturation by international students. There are four main types of acculturation strategies: assimilation, separation, marginalization and integration. We agree that the most successful is integration. It is well known, that the language and speech belong to the important part of the acculturation proses. The language skills can help or slack the acculturation of the international students to the new environment. That means that the langue skills make the adaptation easier and more comfortable and provide successful learning proses. On the other hand the acculturation can take much more time and affect their mental health. It is important for the universities to work out some acculturation programs in order to help and support their international students.
\end{abstract}

Key words: language, speech, acculturation, international students.

\section{Вступ \\ Introduction}

Українські університети щороку активно поповнюються іноземними студентами. Невід’ємною складовою навчального процесу іноземців безумовно $є$ процес їх акультурації. Цей процес може стати легким та цікавим для одних, а також неабияким викликом та випробуванням для інших. У контексті акультурації до іншомовного академічного середовища мова набуває особливо важливого значення та може поставати як позитивним так і негативним чинником акультурації. Рівень володіння мовою країни, котра забезпечує студента освітою, визначає його академічну успішність та впливає на психічне здоров’я загалом. 


\section{Методи та методики дослідження}

Methods and Techniques of the Research

У дослідженні використано такі теоретичні методи дослідження: аналіз, синтез, порівняння, узагальнення, систематизація наукових джерел.

\section{Результати \\ Results}

Уперше вчені звернулися до проблеми акультурації на початку 30-х років XX ст. У перших наукових працях під акультурацією розуміли ті явища, які мають місце, коли групи індивідуумів з різними культурами вступають у довготривалий i безпосередній контакт, внаслідок чого змінюються початкові культурні моделі одної або двох груп (Redfield, 1936; Бахта, 1963).

Згодом термін акультураџія став використовуватися як синонім aдаnтаціï мігрантів в іншокультурному середовищі.

У сучасному розумінні акультурацію розглядають як процес взаємодії культур, в ході якого відбувається їх зміна, засвоєння ними нових елементів (Zick, 2010; Cramer, 2019).

Існує чотири основні форми (стратегіï) акультурації: асиміляція (спосіб акультурації, при якому людина повністю приймає норми і цінності іншої культури, відмовляючись при цьому від своїх); сеnарація - заперечення чужої культури при збереженні ідентифікації зі своєю культурою; маргіналізація - втрата ідентичності 3 власною культурою і відсутність ідентичності з культурою більшості; інтеграція стратегія, за якої відбувається ідентифікація себе як зі старою, так і з новою культурою (Gallois \& Giles, 2015).

На нашу думку, саме інтеграція здатна забезпечити іноземним студентам комфортне перебування у новій країні та успішно навчатися.

Отже, подолання конфліктів, підвищення розуміння між людьми різних культур та національностей пов’язане 3 декількома важливими умовами: зі знанням менталітету, національного характеру співрозмовника, розумінням способу життя та його мови (Ушканова, 2010; Tamimi Sa'd, 2017).

Повертаючись у русло нашої теми варто зауважити, що у багатьох освітніх закладах нажаль не налагоджені чіткі механізми організації навчального процесу для іноземців, котрі не достатньо або і зовсім не володіють українською мовою. Саме тому ця проблема потребує детального вивчення та пошуку шляхів вирішення. 


\section{Висновки}

Conclusions

Отже, мова, як складова будь-якої культури, неодмінно пов'язана 3 процесом акультурації іноземних студентів. 3-поміж асиміляції, сепарації, маргіналізації та інтеграції вважаємо останню стратегію найефективнішою. Вона покликана не забороняти чи відмовлятися від власної культури та мови, а навпаки збагачуватися іноземним мовленням задля власної користі та успіху. Через іноземне мовлення пізнаються усі сфери життя народу, звичаї, традиції, відбувається розуміння суті та особливостей процесу навчання. Саме тому мову та мовлення можна віднести до чинників процесу акультурації іноземних студентів.

\section{Література \\ References}

Бахта, В.М. (1963). Проблема аккультурации в современной этнографической литературе США. Современная американская этнографи (с. 184-222). Москва: Изд-во Академии Наук СССР.

Ушканова, Р.Д. (2010). Логіко-семантичний аналіз акультурації. Вісник Північно-Східного федерального університету ім. М.К. Аммосова, 1(7), 149-153.

Zick, Andreas (2010). Psychologie der Akkulturation. Neufassung eines Forschungsbereiches. Verlag für Sozialwissenschaften / GVW Fachverlage GmbH. Wiesbaden.

Gallois, C., \& Giles, H. (2015). Communication accommodation theory. In K. Tracy, T. Sandel \& C. Ilie (Hrsg.), The International Encyclopedia of Language and Social Interaction. Wiley-Blackwell.

Cramer, Rebecca Eva (2019). Projektbericht «Funktion von Sprache für Identitätskonstruktion und Akkulturationsprozesse». Marburg.

Redfield, R. et al. (1936). Memorandum for the Study of Acculturation. Amerikan Anthropologist, 38, 149-152.

Tamimi Sa'd, S.H. (2017). Foreign language learning and identity reconstruction: Learners' understanding of the intersections of the self, the other and power. CEPS Journal, 7(4), 13-36. 